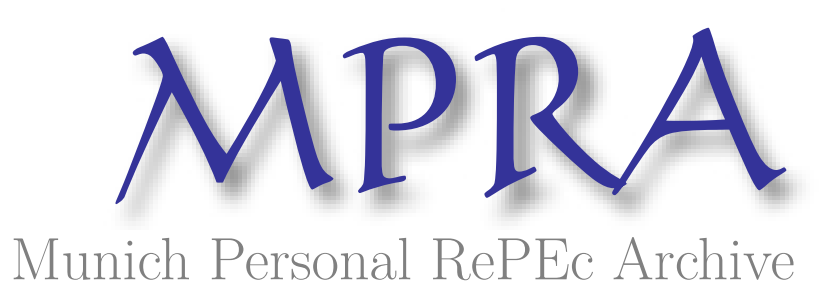

Groups and information disclosure: Evidence on the Olson and Putnam Hypotheses in Japan

Yamamura, Eiji

8 January 2011

Online at https://mpra.ub.uni-muenchen.de/28101/

MPRA Paper No. 28101, posted 18 Jan 2011 15:10 UTC 


\title{
Groups and information disclosure: Evidence on the Olson and Putnam Hypotheses in Japan
}

\begin{abstract}
There is controversy between Putnam and Olson concerning the role of group. Putnam argued that small group makes a contribution to economic growth whereas Olson asserted that small group hampers the economic growth through rent-seeking behavior. Since the end of the 1990s in Japan, there has been a remarkable rise in the rate of enactment of public information-disclosure ordinances by local governments. This paper uses the panel data of Japan to compare the effects of Putnam-type horizontally structured groups and Olson-type vertically structured groups on government information disclosures. The Arellano-Bond type dynamic panel model is employed to control for unobserved fixed effects and endogeneity bias. The major findings are as follows: (1) the Putnam-type group has a positive influence on information disclosure; (2) the Olson-type group has a detrimental effect on information disclosure. These support not only Putnam hypothesis but also Olson Hypothesis. The characteristics of groups should be considered carefully when the influence of group is examined.
\end{abstract}

Keywords:Putnam, Olson, interest group, social capital, information-disclosure ordinance.

JEL classification: G38; P48; Z13 


\section{Introduction}

There are two conflicting views on the role of private associations in economic development. The classic work of Olson (1982) asserted that associations have a tendency to act as special interest groups that lobby for preferential policy at the expense of the rest of society. The typical organization represents a narrow segment of society and has little or no incentive to make any significant sacrifices for the interests of society as a whole. "The organizations are...therefore overwhelmingly oriented to struggle over the distribution of income and wealth rather than to the production of additional output." (Olson 1982, p.44). Organizations that engage in rent seeking can be considered distributional coalitions. These organizations and associations lead to government failure and therefore hamper economic growth. In contrast to Olson's assertion, Putnam (1993) shed light on the positive role played by associations. "Membership in horizontally ordered groups (like sports clubs, cooperatives, mutual aid societies, cultural associations, and voluntary unions) should be positively associated with good government." (Putnam 1993, p.175). 1 Thus, associations make a contribution in preventing government failure, resulting in economic growth.

The influence of groups seems to vary with each group's goals and activities, which are different between Olson- and Putnam-type groups. Previous works concerning the Olson-Putnam controversy have focused mainly on the impact that types of groups have on trust and economic growth (Knack 2003; Pena Lopez \& Sanchez Santos 2007)2. Few researchers have explored the relationship between Olson- or Putnam-type groups and government failure. Groups appear to influence the process of approving public policy, and so the aim of the public policy adopted is thought to depend on the degree of political power of the group. It is thus necessary to investigate the effects that groups exert on policy choice and institutional policy.

Information asymmetry between citizens and government is considered one of the reasons politicians, bureaucrats, and special interest groups can seek their own benefits at the expense of other citizens. Assuming citizens can acquire sufficient information about the government relating to, for instance, the provision of public services or subsidies, citizens can criticize the corrupt behavior of politicians and bureaucrats, leading to increased benefits for the citizens. However, special interest groups are thought to hamper information disclosure since this would be detrimental to the vested

\footnotetext{
1 Putnam also argued that "membership rates in hierarchically ordered organizations...should be negatively associated with good government" (Putnam 1993, p.175), which is not incongruent with Olson's view.

${ }_{2}$ Knack (2003) also examined the effect of group characteristics on economic growth.
} 
interests of its members. In Japan, it has been observed that since the 1990s, an increasing number of local governments have come to enact public information-disclosure ordinances for the purpose of assuring fair governance, ensuring that government activity has become more transparent and enhancing citizens' participation and local autonomy (Uga 2001). The enactment of information-disclosure ordinances seems to reduce the likelihood of government failure.

This paper examines the effect of Olson- and Putnam-type groups on the enactment of public disclosure ordinances to investigate the Putnam and Olson hypotheses. Section 2 briefly reviews the disclosure of local government information in Japan. Section 3 explains the data and methods used. Section 4 discusses the results of the estimations. The final section offers concluding observations.

\section{Review of information disclosure and hypotheses}

\subsection{Disclosure of local government's public information ordinance}

In Japan, the central government enacted the information-disclosure law in 1999, which was about 30 years after the enactment of the Freedom of Information Act in the United States in 1967. Rather than the central government, local governments in Japan at the level of towns and villages have played a leading role in disclosing public information. In 1982, the town of Kanayama in northeastern Japan became the first to enact an information-disclosure ordinance (Muroi 1999). Information-disclosure ordinances signify the regulations of a particular local government providing residents the right to request the disclosure of information possessed by a local government. Figure 1 indicates that the rate of enactment of information-disclosure ordinances rose drastically from 1998 to 2004 . The rate of enactment was about 0.2 in 1998 and reached 0.9 in $2004^{3,4}$. The disclosure of the public information ordinances ensures local government accountability in towns, village, and municipalities. Information-disclosure ordinances are based on the right to know (Muroi, 1999).

Information-disclosure ordinances enable citizens to identify fraudulent interests on the part of politicians, bureaucrats, or private firms. There are various kinds of corrupt

3 This rate becomes 1 if all local government enacted the ordinance.

4 Since 2005, the annexation of municipalities, towns, and villages has rapidly increased. As a result, the number of municipalities, towns, and villages decreased to around 2,300 in 2005, and then to approximately 1,800 in 2009. Accordingly, the rate of municipalities enacting ordinances rose from 0.97 in 2005 to 0.99 in 2009 . Annexation of municipalities is thought to be positively related to the rate of enacting ordinances. That is, the rate of enacting disclosure ordinances is partly affected by the annexation of municipalities. From 2005 to 2009 , the change in the rate of enacting disclosure ordinances was minute. Therefore, I focus on the period of 1998-2004 in this paper. 
uses of public funds, cheating, and collusion. Prior to the mid-1990s, information-disclosure systems were not well developed in most of Japan's local governments. Bureaucrats often claimed expenses for business trips that were not actually undertaken, but this was not disclosed to citizens. In the early 1990s, politicians played essentially the roles of company managers, even though politicians were prohibited by law from engaging in side businesses. Firms managed substantially by politicians frequently received orders for construction work from local governments (Asano, 2010). It has been widely observed that subsidies were provided recklessly to sectors with strong electoral leverage, and local governments spent lavishly on public works projects. The fact that public funds were being illicitly used was revealed by means of information disclosure, and the total amount of such expenditure amounted to 4 billion yen in 1998 (Muroi 1999, p.106). Once an information-disclosure system is in place, the process by which, for example, suppliers of public services are appointed can become transparent, and the inappropriate behavior of politician can be deterred. With such a system, citizens are able to scrutinize the possible collusion among politicians, bureaucrats, and private firms. As a result, in a number of prefectures, the practice of local bureaucrats using public funds to entertain central bureaucrats was in principle abolished (Matsui 2000, p.6). The details of bureaucrats' business trips are now open to the public (Matsui 2000, p.6). Hence, information-disclosure ordinances have made a great contribution to improving the efficiency of local government ${ }^{5}$.

As discussed above, public information-disclosure ordinances lead to the increased welfare of citizens. However, politicians, bureaucrats, and special interest group seem to lose the benefits of information asymmetry between local government and citizens. Hence, they are likely to oppose the disclosure of public information. In the process of enacting information-disclosure law, bureaucrats made an endeavor to emasculate the law (Tsuruoka \& Asaoka 1997).

\subsection{Testable hypothesis}

Japanese society is historically rooted in a group responsibility system within a community. Putnam (1993) argued that groups characterized by a horizontal structure can be viewed as a source of generalized trust and lead to governmental efficiency. Public information-disclosure ordinances lead to an increase in the welfare of citizens and so to the mutual benefit of group members. "Groups that engage in little or no distributional lobbying...may tend to build trust and cooperative habits" (Knack 2003,

\footnotetext{
5 It has been found that the government's public information disclosure is positively associated with GDP growth in Japan (Yamamura 2010b).
} 
342). If this holds true, the members of such groups are likely to participate in collective action, resulting in an increase of benefits for the whole society. That is, horizontally structured groups lead to a positive externality on nonmembers. Compared with Olson-type groups, such as business associations, the gains from rent-seeking activity are less likely to exceed the cost for Putnam-type groups, such as sports clubs, mutual aid societies, cultural associations, and voluntary unions. Information disclosure may not reduce the benefits from information asymmetry between government and citizens for members of Putnam-type groups. The benefits of information disclosure are thus greater for members of Putnam-type groups than loss of information disclosure. These considerations lead to the advancement of Hypothesis 1:

\section{Hypothesis 1: Putnam-type groups enhance the disclosure of public information by governments.}

In Japan, it has been noted that lobbying activity by special interest groups results in governmental inefficiency and numerous budget deficits (Doi \& Ihori 2002; Doi \& Ihori 2009, Ch.7)6. Local governments can acquire an amount of information that is distinctly greater than that available to the citizenry. Owing to such information asymmetry between governments and citizens, politicians and bureaucrats are likely to place higher priority on their own profits than on citizens' welfare, which leads to various undesirable outcomes for society as a whole. Official information-disclosure ordinances enable citizens to collect information regarding governmental activity. Once citizens are able to access such information, they are more inclined to criticize policies that advance politicians' and bureaucrats' self-interest than before. As a result, budget allocations have become more efficient, which results in an increase in citizens' welfare. On the other hand, special interest groups lose the vested interest for their members through rent-seeking activity. That is, thanks to the disclosure of public information by governments, benefits for the whole of society increase whereas the vested interests of special interest groups are reduced. Hence, special interest groups have a strong incentive to prevent public information-disclosure ordinances from being enacted. Members of the group take collective action against the ordinance. Thus, Hypothesis 2 is proposed as follows:

\footnotetext{
6 "Agriculture-related public capital, fishing ports, flood-control measures, and forest conservation have been over-funded as a result of the lobbying activities of local-interest groups" (Doi \& Ihori 2009, p.181).
} 
Hypothesis 2: Olson-type groups impede the disclosure of public information by governments.

\section{Data and method}

\subsection{Data}

Municipalities, towns, and villages are the lowest level of local government. From 1998 to 2004 , there were about 3,200 local governments in the municipalities, towns, and villages in Japan's 47 prefectures 7 ; the number of local governments is thus approximately 68 per prefecture.

Proxy variable data for Olson-type groups were collected from the Establishment and Enterprise Census provided by the Ministry of Internal Affairs and Communications Statistics Bureau. The Establishment and Enterprise Census contains data about various categories of organizations. In the present paper, proxy variables of Olson groups are (1) cooperative associations ${ }^{8}$ and (2) political and business organizations. This is because these organizations are established in part to act as special interest groups to lobby for preferential policies. The number of cooperative associations per population is denoted as OG1, and the number of political and business organizations per population as OG2. These groups are organized for special interest purposes. OG1 and OG2 are incorporated to examine the effects of Olson-type groups on government information disclosure.

Community fire-fighting teams originated in the Edo period (1600-1867), and they have continued to the present (Goto 2001). Community fire-fighting teams, which are informal institutions, are still required today in part because of the relative scarcity of fire stations, which are formal institutions. Such teams play an important role not only in combating fires but also in generating social capital through interpersonal communication in a cooperative protective activity against disasters in general (Goto 2001). Members of such teams regularly patrol within their community to ensure that precautions are taken against fires and other disasters. Community fire-fighting teams clearly make a contribution to reducing the damage caused by natural disasters in Japan (Yamamura 2010 a). The structure of community fire-fighting teams can be regarded as horizontal, bringing together members of equivalent status and power.

7 A Japanese prefecture is roughly the administrative equivalent of an American state or Canadian province.

8 In the Establishment and Enterprise Census, cooperative associations include (a) agriculture, forestry, and fishing cooperative associations and (b) business cooperative associations. 
Thus, the number of fire-fighting teams per population is used as the proxy variable of Putnam-type groups, represented by PG. The numbers of fire-fighting teams is derived from Index Publishing (2006). GDP per capita and number of immigrants comes from the Asahi Shimbun (2008).

The unemployment rate was obtained from the Web site of the Ministry of Internal Affairs and Communications Statistics Bureau. The population census (1990, 2000), as published by the Ministry of Internal Affairs and Communications, provided data about the numbers of people who graduated from universities over the past 10 years; for the period 1990-2000, the data for 1998 to 2000 were generated by interpolations based on the assumption of constantly changing rates between 1990 and 2000. The data between 2001 and 2004 were calculated by adding the annual number of people who graduated from university between 2001 and 2004. The annual data between 2001 and 2004 were collected from the Basic Report for Schools (2001-2004) published by the Ministry of Education, Culture, Sports, Science and Technology. The number of people who graduated from university and population data were used to calculate the rate of people who graduated from university. Definition and basic statistics of variables used in this paper are presented in Table 1.

Table 2 reveals that PG is positively related to OG1 and OG2. I interpret this as suggesting that Olson-type groups are more likely to exist in places where Putnam-type groups exist. It follows from this that the determinants of forming groups are similar regardless of features of the groups. Furthermore, MOBIL(number of migrants from other prefectures per population) is negatively associated with OG1, OG2, and PG, which implies that both Olson-type and Putnam-type groups are less likely to exist in places where population mobility is more conspicuous. Groups enhancing collective action can form more easily when the social network is tighter.

\subsection{Methods}

To examine the hypotheses raised previously, this paper uses the Arellano-Bond type dynamic panel model (Arellano 2003). The estimated function takes the following form:

$$
\begin{aligned}
& D I N F_{i t}=\alpha_{1} D I N F_{i(t-1)}+\alpha_{2} O G 1_{i t}+\alpha_{3} O G 2_{i t}+\alpha_{4} P G_{i t}+\alpha_{5} M O B I L_{i t}+\alpha_{6} U N E M P_{i t}+ \\
& \quad \alpha_{7} G D P_{i t}+\alpha_{7} E D U_{i t}+u_{i}+\varepsilon_{i t},
\end{aligned}
$$

where the dependent variable is $D I N F_{i t}$ in prefecture $i$, for year $t$. $\alpha$ s represent the regression parameters. The lag of dependent variable is included as an independent variable. $u_{i}$ represents the unobservable fixed effects of prefecture $i$. The effect of $u_{i}$ is 
controlled for by the dynamic panel model. $\varepsilon_{i t}$ represents the error term. The structure of the data covers 6 years for 47 prefectures. However, the dynamic panel model takes the first difference, and DINF it lagged two periods or more are used as instruments, which led to 47 observations for two years being discarded. Year dummies are included to capture macroeconomic factors.

The effects of key variables in examining Hypotheses 1 and 2 are as follows: Hypothesis 1 creates the expectation that the coefficient sign of $\mathrm{PG}$ will be positive. In contrast, Hypothesis 2 anticipates that the coefficient signs of OG1 and OG2 will be negative. Putnam defined social capital as "features of social organization, such as trust, norms and networks that can improve the efficiency of society by facilitating coordinated action" (Putnam 1993, p.167). According to Putnam (2000), frequent movers have weaker ties within the community, and so mobile communities seem to have less interactivity with their neighbors than do more stable ones. Put differently, the more mobile a community is, the weaker its internal network becomes. Hence, MOBIL, denoting the number of migrants from other prefecture, can be considered a proxy for the decay of social capital. Social network, one of the features of social capital, appears to enhance collective action within a community (Putnam 1993, 2000). Hence, MOBIL can be considered to be negatively related to the formation not only of Putnam-type but also Olson-type groups. This presumption can be supported by the negative correlation between MOBIL and OG1 (OG2 or PG) exhibited in Table 2. Once the effect of these groups is controlled for by incorporating OG1, OG2, and PG, MOBIL can be considered to capture the other effects of population mobility. In more mobile societies, the long-term benefits from the residential place diminish because residents are more likely to move to other locations. Therefore, residents in more mobile societies are less likely to improve the conditions in their places of residence. This reduces the incentive to require enactment of public information disclosure by local governments even if such disclosure would improve the residential situation. MOBIL is thus predicted to be negative.

Control variables such as UNEMP, GDP, and HC are incorporated to capture the economic condition. Unemployed people appear to be discontent with the performance of local governments because their unemployment is partly caused by the ineffectiveness of such governments. Hence, UNEMP is likely to require information disclosure and so is positive. Highly educated people can interpret the government's information more effectively and so can make use of the information to improve the government, resulting in an increase in welfare. Therefore, highly educated people are more inclined to require information disclosure. The sign of EDU(rate of university graduation) is anticipated to be positive. 


\subsection{Endogeneity bias}

GDP and unemployment rate seem to affect the decision making of local governments about the enactment of information disclosure. Conversely, there is the possibility of reverse causality, whereby the enactment of information disclosure influences the GDP and unemployment rate. Government public information disclosure is believed to make the government allocate resources more efficiently, thereby increasing GDP and reducing the unemployment rate 9 . In addition, people will tend to move to a place where they can earn a higher income. Information disclosure possibly affects the income level and therefore has an influence on MOBIL. If this holds true, the causality between enactment of information disclosure and GDP (UNEMP or MOBIL) should be considered ambiguous. Hence, the estimation results appear to suffer from endogeneity bias. GDP, UNEMP, and MOBIL are treated as endogenous variables in the dynamic panel model for the purpose of controlling for the estimation bias ${ }^{10}$. I use the level of endogenous variable lagged two periods or more as additional instrumental variables (Arellano 2003, p.168).

\section{Results}

The results of the dynamic panel model are shown in Tables 3, 4 and 5. All estimations control for the exogenous macrolevel shock by including year dummies as independent variables. As presented in Table 2, the correlation coefficient between OG1 and OG2 is 0.66 , suggesting a multicollinearity between OG1 and OG2. With the aim of alleviating the effect of multicollinearity, in addition to the full model including OG1 and OG2, I also present alternative specifications that do not simultaneously include OG1 and OG2. In column 1 of Tables 3 and 4, and columns 1 and 4 of Table 5, the results of the full model are reported. In the remaining columns of Tables 3, 4, and 5, the results of alternative specifications are presented. The results of baseline estimates, which treat all independent variables as exogenous, are exhibited in Table 3. The results of estimations that treat MOBIL, UNEMP, and GDP as endogenous are shown in Table 4. Table 5 presents the results of estimates that treat all independent variables as endogenous.

Tables 3, 4, and 5 provide the results of Sargan's over-identification test and

9 By using OECD data, Alt \& Lassen (2006) provided the evidence that fiscal transparency decreases debt accumulation.

10 Baliamoune-Lutz (2009) used the dynamic panel model to alleviate endogenous bias by treating various independent variables as endogenous. 
second-order serial correlation test (Arellano 2003). These tests are necessary to check the validity of the estimation results in the dynamic panel model. The null hypothesis of Sargan's over-identification test is that the instrumental variables do not correlate with the residuals. If the hypothesis is not rejected, the instrumental variables are valid. Furthermore, the test for the null hypothesis (that there is no second-order serial correlation with disturbances in the first-difference equation) is important because the estimator is consistent when there is no second-order serial correlation. Tables 3, 4, and 5 show that both hypotheses are not rejected in all estimations, suggesting that the estimation results are valid.

In all columns of Table 3, the coefficients of OG1 and OG2 are, as anticipated, negative, while the coefficient of PG is positive. Also, OG2 and PG are statistically significant at the $1 \%$ level, OG1 is statistically significant at the $10 \%$ level in column 2 . This is consistent with Hypotheses 1 and 2. Furthermore, the absolute values of the PG coefficient are approximately 10 , which is about 8-10 times greater than those of OG1 and OG2. That is, the Putnam effect is distinctly greater than the Olson effect. A significant negative value for MOBIL in all columns is in accordance with expectations. For control variables, GDP is positive, while being statistically significant in all columns. Other control variables are not statistically significant.

The results presented in Table 4 are consistent with Hypotheses 1 and 2: the coefficients of OG1 and OG2 are negative, whereas that of $\mathrm{PG}$ is positive in all columns. In particular, OG2 and PG continue to be statistically significant at the $1 \%$ level. The absolute values of the PG coefficient are from 6.86 to 8.53, which are smaller than those in Table 3. Conversely, both absolute values of OG1 and OG2 are greater than those in Table 3. Hence, the difference in effect of Putnam's and Olson's groups becomes smaller after controlling for endogeneity bias in economic variables. MOBIL continues to be negative and statistically significant. The results of control variables are not stable, and so their effects are ambiguous. The results of alternative specifications presented in Table 5 are similar to those in Table4, suggesting that the results of estimations are robust.

The combined results of Tables 3, 4, and 5 strongly support Hypotheses 1 and 2, which implies that both Putnam- and Olson-group effects on enacting public information disclosure are observable at the same time.

\section{Conclusion}

Olson (1982) argued that a social group is apt to lobby for preferential policy for its 
members at the expense of the rest of society. This in part causes failures on the part of government. In contrast, Putnam (1993) asserted that a horizontally structured group fosters institutional success, reducing the likelihood of government failure. The conflict between Putnam's and Olson's ideas has not been sufficiently examined. This paper aims to examine the effects of Putnam- and Olson-type groups on government quality by using the panel dataset of Japan.

In Japan, since the end of 1990s, local governments have actively enhanced information disclosure. Hence, there has been a remarkable rise in the rate of enactment of information-disclosure ordinances by local governments: various closed information areas can be accessed by citizens if they request them to be opened. When information-disclosure ordinances are enacted, special interest groups lobby for preferential policy and engage in rent seeking. This is because citizens are likely to criticize the government when it favors the special interest group at the expense of other citizens' benefits. Hence, the Olson-type group has an incentive to prevent such ordinances from being enacted. On the other hand, the Putnam-type group is thought to prefer information disclosure because this makes a contribution to improving government transparency, leading to benefits to the whole of society. In enacting information-disclosure ordinances, both Olson- and Putnam-type groups are thus anticipated to play a critical role. Investigating these groups' effects on ordinance enactment is thought to be an appropriate empirical case study for exploring the Olson and Putnam hypotheses.

I used the Arellano-Bond type dynamic panel model to control for unobserved fixed effects and endogeneity bias. The major findings are summarized as follows: (1) the Putnam-type group has a positive influence on information disclosure; (2) the Olson-type group has a detrimental effect on information disclosure.

Compared with the existing literature examining the effects of Putnam- and Olson-type groups on trust and growth (Knack 2003; Pena Lopez \& Sanchez Santos 2007), the primary contribution of this paper is twofold. First, the present study provides a definite understanding of the effect of groups on the choice of public policy. Second, it elucidates the opposite effects of Putnam- and Olson-type groups on policy choice. This paper, however, did not compare the influences between Putnam- and Olson-type groups regarding various political and economic issues, such as public spending, deficits, and government size, nor does it present a theoretical framework on which to base results. These issues should be researched to explore the questions of how and to what extent Putnam- and Olson-type groups have a different role in public economic issues. Finally, the sample size was small in this study, and larger samples are 
recommended in future. 


\section{References}

Alt, J.E., \& Lassen, D.D. (2006). Fiscal transparency, political parties, and debt in OECD countries. European Economic Review, 50, 1403-1439.

Arellano, M. (2003). Panel data econometrics. New York: Oxford University Press.

Asahi Shimbun. (2008). Minryoku: Todofuken-betsu minryoku sokutei shiryoshu (CD-ROM edition), Asahi-Newspaper, Tokyo.

Asano, E. (2010). Local government reform promoted by information disclosure (Johokokai de susumeru jichitai kaikaku: Shuzai noto ga akasu katsuyo-jutsu.). Tokyo: Jichitaikenkyu-sha.

Baliamoune-Lutz, M. (2009). Human well-being effects of institutions and social capital. Contemporary Economic Policy, 27(1), 54-66.

Downs, A. (1957). An economic theory of democracy. New York: Harper and Row.

Doi, T., \& Ihori, T. (2002). Fiscal reconstruction and local interest groups in Japan. Journal of Japanese and International Economies, 16, 492-511.

Doi, T., \& Ihori, T. (2009). The public sector in Japan: Past development and future prospects. Cheltenham: Edward Elgar.

Dworkin, R. (1977). Taking rights seriously. London, Duckworth.

Goto, I. (2001). Tracing the origin of the communal fire-fighting team: Communal firefighting team in the 21st century (Shobo-dan no genkryu o tadoru: 21seki no shobo-dan no arikata). Tokyo: Kindaishobo-sha.

Greene, W.H. (1997). Econometric Analysis (3 eds), Prentice-Hall, London.

Heckelman, J. (2000). Consistent estimates of the impact of special interest groups on economic growth. Public Choice, 104, 319-327.

Helliwell, J.F. (2003). How's life? Combining individual and national variables to explain subjective well-being. Economic Modeling, 20, 331-360.

Helliwell, J.F., \& Huang, W. (2008). How's your government? International evidence linking good government and well-being. British Journal of Political Science, $38,595-619$.

Index Publishing. (2006). Chiiki Tokei (CD-ROM edition). Tokyo: Index Publishing..

Knack, S. (2002). Social capital and government performance: Evidence from states. American Journal of Political Science, 46, 772-785,

Knack, S. (2003). Groups, growth and trust: Cross-country evidence on the Olson and Putnam hypotheses. Public Choice, 117, 341-55.

Matsui, S. (2000). An introduction to the information disclosure law (Johokokai ho nyumon). Tokyo: Iwanami-shoten. 
Muroi, C. (1999). Exhortation towards disclosure of local governments' information. (Jichitai johokoai no susume). Tokyo: Junpo-sha.

Niskanen, W. (1971). Bureaucracy and representative government. Chicago: Aldine-Atherton.

Olson, M. (1965). The logic of collective action. Cambridge, MA: Harvard University Press.

Olson, M. (1982). The rise and decline of nations. New Haven: Yale University Press.

Putnam, R.D. (1993) Making democracy work: Civic traditions in modern Italy. Princeton: Princeton University Press.

Putnam, R.D. (2000). Bowling alone: The collapse and revival of American community. New York: Simon and Schuster.

Pena Lopez, J.A. \& Sanchez Santos, J.M. (2007). The Olson-Putnam controversy: Some empirical evidence. Economics Bulletin, 26(4), 1-10.

Ministry of Internal Affairs and Communications Statistics Bureau (various years). Establishment and enterprise census. Tokyo: Ministry of Internal Affairs and Communications Statistics Bureau.

Turuoka, K., \& Asaoka, M. (1997). Information disclosure in Japan: Resistant bureaucrats. (Nihon-no johokokai: Teikosuru kanryo). Tokyo: Kaden-sha.

Uga, K. (2001). Information disclosure law and information disclosure ordinances. (Johokokai ho, johokokai jorei.). Tokyo: Yuhikaku.

Yamamura, E. (2010a). Learning effect and social capital: A case study of natural disaster from Japan. Regional Studies, 44 (8), 1019-1032.

Yamamura, E. (2010 b). Public policy, trust and growth: Disclosure of government information in Japan. MPRA Paper 27703. 


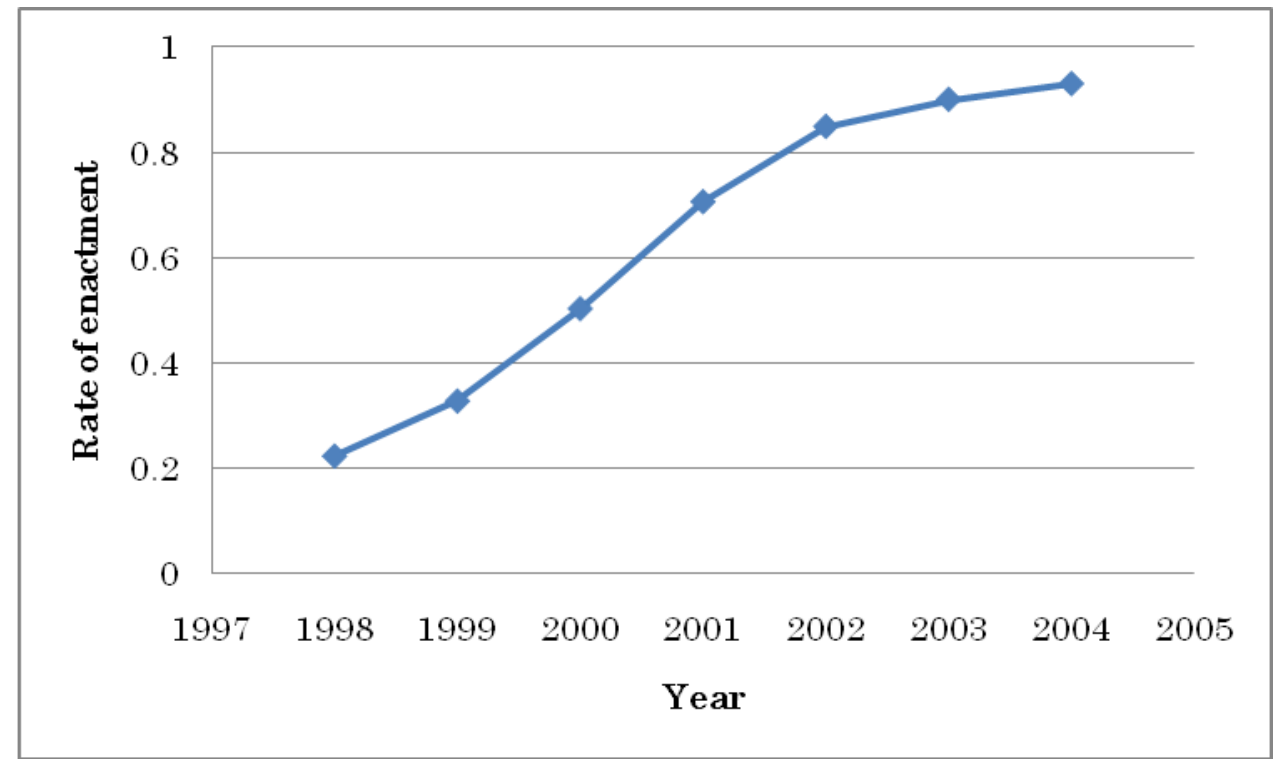

Fig.1 Rates of enactment by municipalities of government information-disclosure ordinances.

Note: The rate becomes 1 if all local government enacted the ordinance. 
Table 1. Variable definitions and basic statistics

\begin{tabular}{|c|c|c|c|}
\hline Variable & Definition & Mean & $\begin{array}{l}\text { Standard } \\
\text { deviation }\end{array}$ \\
\hline$D I N F$ & $\begin{array}{l}\text { Rates of municipalities enacting } \text { government } \\
\text { information-disclosure ordinances } \\
\text { (municipalities enacting ordinances/all municipalities) }\end{array}$ & 0.63 & 0.32 \\
\hline$O G 1$ & $\begin{array}{l}\text { Number of cooperative associations per population } \\
\text { (number of cooperative associations/1,000 persons) }\end{array}$ & 0.31 & 0.13 \\
\hline OG2 & $\begin{array}{l}\text { Number of political and business organizations per } \\
\text { population. } \\
\text { (number of political and business organizations } / 1,000 \\
\text { persons) }\end{array}$ & 0.35 & 0.11 \\
\hline$P G$ & $\begin{array}{l}\text { Numbers of fire-fighting teams per population } \\
\text { (number of fire-fighting teams } / 1,000 \text { persons) }\end{array}$ & 0.31 & 0.14 \\
\hline$M O B I L$ & $\begin{array}{l}\text { Number of migrants from other prefectures per } \\
\text { population } \\
\text { (number of migrants from other prefectures } / 1,000 \\
\text { persons) }\end{array}$ & 19.5 & 4.85 \\
\hline$U N E M P$ & Unemployment rate $(\%)$ & 4.46 & 1.10 \\
\hline$G D P$ & GDP (in millions of yen) & 3.57 & 0.74 \\
\hline$E D U$ & Rate of university graduation & 0.09 & 0.03 \\
\hline
\end{tabular}

${ }^{1}$ Data were collected from the Asahi Shimbun newspaper (2008) and the Ministry of Internal Affairs and Communications Statistics Bureau (various years). 
Table 2. Correlation matrix of variables used for estimation

\begin{tabular}{|c|c|c|c|c|c|c|c|c|}
\hline & DISCINF & $O G 1$ & OG2 & $P G$ & MOBIL & $U N E M P$ & $G D P$ & $H C$ \\
\hline$\overline{D I N F_{t-1}}$ & 1.00 & & & & & & & \\
\hline$O G 1_{t}$ & -0.21 & 1.00 & & & & & & \\
\hline$O G 2_{t}$ & -0.06 & 0.66 & 1.00 & & & & & \\
\hline$P G_{t}$ & -0.10 & 0.67 & 0.38 & 1.00 & & & & \\
\hline$M O B I L_{t}$ & -0.05 & -0.48 & -0.23 & -0.47 & 1.00 & & & \\
\hline$U N E M P_{t}$ & 0.09 & -0.47 & -0.07 & -0.28 & 0.18 & 1.00 & & \\
\hline$G D P_{t}$ & 0.21 & -0.28 & 0.0003 & 0.43 & 0.36 & -0.11 & 1.00 & \\
\hline$H C_{t}$ & 0.25 & -0.62 & -0.44 & -0.62 & 0.73 & 0.18 & 0.53 & 1.00 \\
\hline
\end{tabular}


Table 3. Dynamic panel model with DISCINF $\mathrm{t}_{\mathrm{t}}$ as dependent variable

\begin{tabular}{|c|c|c|c|}
\hline & (1) & (2) & (3) \\
\hline$D I N F_{t-1}$ & $\begin{array}{l}0.67 * * * \\
(9.28)\end{array}$ & $\begin{array}{l}0.71^{* * *} \\
(10.8)\end{array}$ & $\begin{array}{l}0.66 * * * \\
(9.02)\end{array}$ \\
\hline$O G 1_{t}$ & $\begin{array}{l}-0.84 \\
(-1.62)\end{array}$ & $\begin{array}{l}-0.97^{*} \\
(-1.87)\end{array}$ & \\
\hline$O G 2_{t}$ & $\begin{array}{l}-1.23 * * * \\
(-2.67)\end{array}$ & & $\begin{array}{l}-1.62^{* * *} \\
(-3.37)\end{array}$ \\
\hline$P G_{t}$ & $\begin{array}{l}10.4^{* * *} \\
(4.04)\end{array}$ & $\begin{array}{l}8.79 * * * \\
(3.39)\end{array}$ & $\begin{array}{l}10.8^{* * * *} \\
(4.14)\end{array}$ \\
\hline$M O B I L_{t}$ & $\begin{array}{l}-0.05^{* * *} \\
(-3.39)\end{array}$ & $\begin{array}{l}-0.04^{* * *} \\
(-3.06)\end{array}$ & $\begin{array}{l}-0.04 * * * \\
(-3.30)\end{array}$ \\
\hline$U N E M P_{t}$ & $\begin{array}{l}-0.03 \\
(-1.09)\end{array}$ & $\begin{array}{l}-0.02 \\
(-0.91)\end{array}$ & $\begin{array}{l}-0.02 \\
(-1.04)\end{array}$ \\
\hline$G D P_{t}$ & $\begin{array}{l}20.7 * * \\
(2.01)\end{array}$ & $\begin{array}{l}21.1^{* *} \\
(2.03)\end{array}$ & $\begin{array}{l}20.4^{* *} \\
(1.94)\end{array}$ \\
\hline$H C_{t}$ & $\begin{array}{l}-1.59 \\
(-0.85)\end{array}$ & $\begin{array}{l}-1.26 \\
(-0.67)\end{array}$ & $\begin{array}{l}-1.68 \\
(-0.94)\end{array}$ \\
\hline Constant & $\begin{array}{l}-1.56 * \\
(-1.75) \\
\end{array}$ & $\begin{array}{l}-1.52 \\
(-1.56)\end{array}$ & $\begin{array}{l}-1.82^{* *} \\
(-2.16)\end{array}$ \\
\hline Year dummy & Yes & Yes & Yes \\
\hline $\begin{array}{l}\text { Sargan test } \\
<P_{\text {value }}>\end{array}$ & $\begin{array}{l}18.2 \\
<0.19>\end{array}$ & $\begin{array}{l}19.0 \\
<0.16>\end{array}$ & $\begin{array}{l}18.6 \\
<0.17>\end{array}$ \\
\hline Serial correlation & -0.55 & -0.55 & -0.50 \\
\hline $\begin{array}{l}\text { Second-order } \\
<P \text { value }>\end{array}$ & $<0.57>$ & $<0.57>$ & $<0.61>$ \\
\hline Observations & 232 & 232 & 233 \\
\hline
\end{tabular}

${ }^{1}$ Numbers in parentheses are z-statistics.

2 "Yes" signifies that year dummies are included as independent variables. $*, * *$, and $* * *$ indicate significance at $10 \%, 5 \%$, and $1 \%$ levels, respectively. 
Table 4. Dynamic panel model with endogenous variables and DISCINF $\mathrm{t}_{\mathrm{t}}$, as dependent variable

\begin{tabular}{|c|c|c|c|}
\hline & (1) & (2) & (3) \\
\hline$\overline{D I N F_{t-1}}$ & $\begin{array}{l}0.59^{* * *} \\
(20.3)\end{array}$ & $\begin{array}{l}0.61^{* * *} \\
(20.6)\end{array}$ & $\begin{array}{l}0.61^{* * *} \\
(26.2)\end{array}$ \\
\hline$O G 1_{t}$ & $\begin{array}{l}-1.00^{*} \\
(-1.74)\end{array}$ & $\begin{array}{l}-1.41^{* *} \\
(-2.41)\end{array}$ & \\
\hline$O G 2_{t}$ & $\begin{array}{l}-3.34^{* * *} \\
(-2.76)\end{array}$ & & $\begin{array}{l}-3.86 * * * \\
(-4.04)\end{array}$ \\
\hline$P G_{t}$ & $\begin{array}{l}8.53^{* * *} \\
(4.61)\end{array}$ & $\begin{array}{l}7.72^{* * * *} \\
(4.83)\end{array}$ & $\begin{array}{l}6.86^{* * * *} \\
(4.60)\end{array}$ \\
\hline$M O B I L_{t}$ & $\begin{array}{l}-0.05^{* * *} \\
(-7.02)\end{array}$ & $\begin{array}{l}-0.05^{* * *} \\
(-7.04)\end{array}$ & $\begin{array}{l}-0.04^{* * *} \\
(-6.70)\end{array}$ \\
\hline$U N E M P_{t}$ & $\begin{array}{l}0.01 \\
(0.99)\end{array}$ & $\begin{array}{l}0.02 \\
(1.42)\end{array}$ & $\begin{array}{l}0.03^{*} \\
(2.15)\end{array}$ \\
\hline$G D P_{t}$ & $\begin{array}{l}-0.85 \\
(-0.13)\end{array}$ & $\begin{array}{l}11.3^{*} \\
(1.68)\end{array}$ & $\begin{array}{l}-5.19 \\
(-0.95)\end{array}$ \\
\hline$H C_{t}$ & $\begin{array}{l}2.07 \\
(1.15)\end{array}$ & $\begin{array}{l}3.77^{*} \\
(1.96)\end{array}$ & $\begin{array}{l}0.96 \\
(0.83)\end{array}$ \\
\hline Constant & $\begin{array}{l}0.17 \\
(0.17)\end{array}$ & $\begin{array}{l}-1.46^{*} \\
(-1.80)\end{array}$ & $\begin{array}{l}0.63 \\
(0.93)\end{array}$ \\
\hline Year dummy & Yes & Yes & Yes \\
\hline $\begin{array}{l}\text { Endogenous } \\
\text { variables }\end{array}$ & $\begin{array}{l}\text { MOBIL } \\
\text { UNEMP } \\
\text { GDP }\end{array}$ & $\begin{array}{l}\text { MOBIL } \\
\text { UNEMP } \\
\text { GDP }\end{array}$ & $\begin{array}{l}\text { MOBIL } \\
\text { UNEMP } \\
\text { GDP }\end{array}$ \\
\hline $\begin{array}{l}\text { Sargan test } \\
<P \text {-value }> \\
\text { Serial } \\
\text { correlation }\end{array}$ & $\begin{array}{l}33.9 \\
<0.99> \\
-0.75 \\
<0.45>\end{array}$ & $\begin{array}{l}37.1 \\
<0.97> \\
-0.93 \\
<0.34>\end{array}$ & $\begin{array}{l}34.0 \\
<0.99> \\
-0.65 \\
<0.51>\end{array}$ \\
\hline $\begin{array}{l}\text { Second-order } \\
<P \text {-value }> \\
\text { Observations }\end{array}$ & 232 & 232 & 232 \\
\hline
\end{tabular}

${ }^{1}$ Numbers in parentheses are $\mathrm{z}$-statistics.

2 "Yes" signifies that year dummies are included as independent variables. $*, * *$, and $* * *$ indicate significance at $10 \%, 5 \%$, and $1 \%$ levels, respectively. 
Table 5. Dynamic panel model with endogenous variables and DISCINF $\mathrm{t}_{\mathrm{t}}$ as dependent variable

\begin{tabular}{|c|c|c|c|c|c|c|}
\hline & (1) & (2) & (3) & (4) & (5) & (6) \\
\hline$D I N F_{t-1}$ & $\begin{array}{l}0.61^{* * * *} \\
(18.7)\end{array}$ & $\begin{array}{l}0.65^{* * *} \\
(18.3)\end{array}$ & $\begin{array}{l}0.64^{* * *} \\
(24.3)\end{array}$ & $\begin{array}{l}0.54^{* * *} \\
(15.6)\end{array}$ & $\begin{array}{l}0.53^{* * *} \\
(22.4)\end{array}$ & $\begin{array}{l}0.50^{* * *} \\
(14.4)\end{array}$ \\
\hline$O G 1_{t}$ & $\begin{array}{l}-1.00^{*} \\
(-1.97)\end{array}$ & $\begin{array}{l}-1.56^{* * *} \\
(-3.37)\end{array}$ & & $\begin{array}{l}-0.09 \\
(-0.22)\end{array}$ & $\begin{array}{l}-1.06^{* * *} \\
(-2.66)\end{array}$ & \\
\hline$O G 2_{t}$ & $\begin{array}{l}-2.08 \\
(-1.49)\end{array}$ & & $\begin{array}{l}-4.46 * * * \\
(-4.03)\end{array}$ & $\begin{array}{l}-3.46^{* * * *} \\
(-3.15)\end{array}$ & & $\begin{array}{l}-4.78 * * * \\
(-3.83)\end{array}$ \\
\hline$P G_{t}$ & $\begin{array}{l}12.2^{* * *} \\
(4.66)\end{array}$ & $\begin{array}{l}13.4^{* * * *} \\
(4.91)\end{array}$ & $\begin{array}{l}15.2^{* * *} \\
(7.11)\end{array}$ & $\begin{array}{l}10.2^{* * * *} \\
(5.74)\end{array}$ & $\begin{array}{l}10.9^{* * * *} \\
(4.38)\end{array}$ & $\begin{array}{l}13.2^{* * * *} \\
(5.99)\end{array}$ \\
\hline$M O B I L_{t}$ & $\begin{array}{l}-0.04^{* * *} \\
(-3.89)\end{array}$ & $\begin{array}{l}-0.04^{* * *} \\
(-4.76)\end{array}$ & $\begin{array}{l}-0.05^{* * *} \\
(-5.65)\end{array}$ & $\begin{array}{l}-0.03^{* * *} \\
(-3.70)\end{array}$ & $\begin{array}{l}-0.03^{* * *} \\
(-5.44)\end{array}$ & $\begin{array}{l}-0.04^{* * *} \\
(-4.90)\end{array}$ \\
\hline$U N E M P_{t}$ & $\begin{array}{l}-0.01 \\
(-0.65)\end{array}$ & $\begin{array}{l}-0.01 \\
(-1.37)\end{array}$ & $\begin{array}{l}-0.01 \\
(-1.06)\end{array}$ & $\begin{array}{l}0.02 \\
(1.60)\end{array}$ & $\begin{array}{l}0.04^{* * *} \\
(3.04)\end{array}$ & $\begin{array}{l}0.02 \\
(1.63)\end{array}$ \\
\hline$G D P_{t}$ & $\begin{array}{l}14.3 \\
(1.30)\end{array}$ & $\begin{array}{l}34.0^{* * *} \\
(4.04)\end{array}$ & $\begin{array}{l}1.56 \\
(1.06)\end{array}$ & $\begin{array}{l}19.1^{*} \\
(2.06)\end{array}$ & $\begin{array}{l}31.2^{* * *} \\
(3.31)\end{array}$ & $\begin{array}{l}11.9^{*} \\
(2.12)\end{array}$ \\
\hline$H C_{t}$ & $\begin{array}{l}-0.43 \\
(-0.39)\end{array}$ & $\begin{array}{l}0.28 \\
(0.23)\end{array}$ & $\begin{array}{l}-0.93 \\
(-0.83)\end{array}$ & $\begin{array}{l}-3.73^{*} \\
(-1.67)\end{array}$ & $\begin{array}{l}1.28 \\
(0.61)\end{array}$ & $\begin{array}{l}-2.18 \\
(-1.18)\end{array}$ \\
\hline Constant & $\begin{array}{l}-1.73^{*} \\
(-1.69)\end{array}$ & $\begin{array}{l}-3.52^{* * *} \\
(-3.98)\end{array}$ & $\begin{array}{l}-1.42 \\
(-1.28)\end{array}$ & $\begin{array}{l}-1.24 \\
(-1.42)\end{array}$ & $\begin{array}{l}-3.39 * * * \\
(-3.57)\end{array}$ & $\begin{array}{l}-1.29 \\
(-1.64)\end{array}$ \\
\hline Year dummy & Yes & Yes & Yes & Yes & Yes & Yes \\
\hline $\begin{array}{l}\text { Endogenous } \\
\text { variables }\end{array}$ & $\begin{array}{l}\text { OG1 } \\
\text { OG2 } \\
\text { PG } \\
\text { MOBIL }\end{array}$ & $\begin{array}{l}\text { OG1 } \\
\text { PG } \\
\text { MOBIL }\end{array}$ & $\begin{array}{l}\text { OG2 } \\
\text { PG } \\
\text { MOBIL }\end{array}$ & $\begin{array}{l}\text { OG1 } \\
\text { OG2 } \\
\text { PG } \\
\text { MOBIL } \\
\text { UNEMP } \\
\text { GDP } \\
\text { HC }\end{array}$ & $\begin{array}{l}\text { OG1 } \\
\text { PG } \\
\text { MOBIL } \\
\text { UNEMP } \\
\text { GDP } \\
\text { HC }\end{array}$ & $\begin{array}{l}\text { OG2 } \\
\text { PG } \\
\text { MOBIL } \\
\text { UNEMP } \\
\text { GDP } \\
\text { HC }\end{array}$ \\
\hline $\begin{array}{l}\text { Sargan test } \\
\langle P \text { value }> \\
\text { Serial } \\
\text { correlation }\end{array}$ & $\begin{array}{l}27.5 \\
<0.99> \\
-0.74 \\
<0.45>\end{array}$ & $\begin{array}{l}29.9 \\
<0.99> \\
-0.74 \\
<0.45>\end{array}$ & $\begin{array}{l}27.2 \\
<0.99> \\
-0.48 \\
<0.62>\end{array}$ & $\begin{array}{l}35.8 \\
<1.00> \\
-0.61 \\
<0.53>\end{array}$ & $\begin{array}{l}34.5 \\
<1.00> \\
-1.18 \\
<0.23>\end{array}$ & $\begin{array}{l}32.5 \\
<1.00> \\
-0.77 \\
<0.43>\end{array}$ \\
\hline $\begin{array}{l}\text { Second-order } \\
<P \text { value }> \\
\text { Observations }\end{array}$ & 232 & 232 & 232 & 232 & 232 & 232 \\
\hline
\end{tabular}

${ }^{1}$ Numbers in parentheses are z-statistics.

2 "Yes" signifies that year dummies are included as independent variables.

$*, * *$, and $* * *$ indicate significance at $10 \%, 5 \%$, and $1 \%$ levels, respectively. 